\title{
Peningkatan Kemampuan Kerja Sama melalui Kegiatan Kerja Kelompok Pada Anak Kelompok A TK Kartika Salo Kabupaten Kampar
}

\author{
Moh Fauziddin \\ Dosen Prodi PG-PAUD STKIP Pahlawan Tuanku Tambusai \\ mfauziddin@gmail.com
}

\begin{abstract}
ABSTRAK
Tujuan penelitian ini adalah meningkatkan kemampuan kerja sama anak melalui kegiatan kerja kelompok pada anak Kelompok A Taman Kanak-kanak (TK) Kartika Salo Kabupaten Kampar. Kegiatan kerja kelompok dipilih karena kegiatan ini dapat menggerakan anak melakukan kerjasama dengan baik. Jenis penelitian ini adalah penelitian tindakan kelas kolaboratif yang menggunakan model Kemmis dan Mc Taggart. Subjek pada penelitian ini adalah 16 anak Kelompok A TK Kartika Salo Kampar yang terdiri dari 6 anak laki-laki dan 10 anak perempuan. Objek penelitian ini yaitu kemampuan kerja sama anak yang meliputi kemampuan berinteraksi, tanggung jawab, dan saling membantu. Metode pengumpulan data yang digunakan adalah observasi dan dokumentasi. Instrumen yang digunakan adalah lembar observasi. Teknik analisis data dilakukan secara deskriptif kuantitatif. Indikator keberhasilan dalam penelitian ini adalah apabila perhitungan persentase seluruh aspek menunjukkan nilai 80\%. Hasil penelitian ini menunjukkan bahwa kemampuan kerja sama anak meningkat setelah adanya tindakan melalui kegiatan kerja kelompok. Dari data Siklus I persentase kemampuan kerja sama anak 65\%. Pada Siklus II kemampuan kerja sama anak mengalami peningkatan menjadi 93\%. Dapat dikatakan bahwa penelitian ini berhasil karena persentase sudah melebihi angka yang ditentukan, yakni $80 \%$.
\end{abstract}

Kata kunci: kemampuan kerja sama, kerja kelompok 


\section{Pendahuluan}

Pendidikan Anak Usia Dini (PAUD) merupakan jenjang pendidikan sebelum pendidikan dasar yang berperan membina peserta didik usia 0-6 tahun dalam mengoptimalkan aspek-aspek perkembangannya. Menurut PP Nomor 27 Tahun 1990, Bab I Pasal 1,Taman Kanak-kanak (TK) merupakan salah satu bentuk Pendidikan Anak Usia Dini pada jalur pendidikan formal. TK merupakan salah satu bentuk penyelenggaraan pendidikan yang secara spesifik bertujuan mengoptimalkan pertumbuhan dan perkembangan yang meliputi fisik motorik, sosial emosional (sikap dan perilaku serta agama), bahasa, moral dan agama, dan kognitif, sesuai dengan keunikan dan tahap-tahap perkembangan yang dilalui oleh anak usia dini.

Usia dini merupakan usia emas, yang mana berbagai pertumbuhan dan perkembangan mulai dan sedang berlangsung, seperti perkembangan fisiologis, bahasa, sosial emosional, motorik dan kognitif. Perkembangan ini akan menjadi dasar bagi perkembangan anak selanjutnya. Oleh sebab itu perkembangan pada masa awal ini akan menjadi penentu bagi perkembangan selanjutnya. Keberhasilan dalam menjalankan tugas perkembangan pada suatu masa akan menentukan keberhasilan pada masa perkembangan berikutnya.

Menurut Hurlock (1980:86-87) hanya ada sedikit bukti yang menyatakan bahwa sikap sosial atau antisosial merupakan sikap bawaan, kemampuan tersebut tergantung pada pengalaman-pengalaman sosial. Kehidupan awal anak berpusat di sekitar rumah, maka di rumahlah diletakkan dasar perilaku dan sikap sosial kelak. Jadi anak merupakan makhluk sosial yang tidak bisa hidup sendiri (zoon politicon) dan agar anak mampu menjalin hubungan yang baik dengan orang lain, maka orangtua dan guru memiliki peran penting untuk mengembangkan kemampuan sosial-emosional anak. Kemampuan sosial- emosional merupakan kemampuan yang harus dimunculkan, dilatihkan serta dikembangkan melalui pembinaan, pembiasaan dan pengajaran sejak dini seperti halnya di TK.
Dewasa ini pendidikan lebih menekankan pada ranah kecerdasan intelektual, sedangkan kemampuan lain seperti fisik motorik, seni, dan sosial- emosional kurang diperhatikan. Kecerdasan sosial-emosional penting bagi anak karena dengan dimilikinya kecerdasan ini maka seorang anak dapat diterima oleh lingkungan atau temannya. Menurut Lwin (2008: 197-198), anak yang memiliki kemampuan sosial yang baik dapat dilihat dari seberapa dekat dia bisa berteman atau bersahabat, seberapa mudah dia akrab dengan orang asing dan jarang memiliki konflik dengan temannya.

Kemampuan bekerja sama merupakan salah satu kemampuan dalam pola perilaku sosial (Hurlock, 1978: 262). Semakin banyak kesempatan yang anak miliki untuk melakukan suatu hal bersama-sama, semakin cepat anak belajar melakukannya dengan cara bekerja sama

Permendiknas Nomor 58 Tahun 2009, dijelaskan bahwa salah satu perkembangan sosialemosional Kelompok A atau anak usia 4-5 tahun yaitu dapat bekerja sama dalam menyelesaikan tugas dan saling membantu sesama teman.

Berdasarkan hasil observasi 4 Januari 2016 pada 16 anak Kelompok A di TK Kartika Salo, pada proses belajar terlihat bahwa kemampuan bekerja sama anak masih kurang optimal. Hal ini dapat dilihat pada tabel berikut ini.

Tabel 1.1 Kemampuan Kerjasama anak kelompok

A TK Kartika Salo

\begin{tabular}{|l|l|l|l|}
\hline \multirow{7}{*}{ Aspek } & Kriteria & $\begin{array}{l}\text { Jumlah } \\
\text { Anak } \\
18 \text { Orang }\end{array}$ & Persentase \\
\hline \multirow{5}{*}{ Interaksi } & Baik & - & $0 \%$ \\
\cline { 2 - 4 } & $\begin{array}{l}\text { Cukup } \\
\text { Baik }\end{array}$ & 3 & $16,7 \%$ \\
\cline { 2 - 4 } & $\begin{array}{l}\text { Kurang } \\
\text { baik }\end{array}$ & 8 & $44,4 \%$ \\
\cline { 2 - 4 } & $\begin{array}{l}\text { Tidak } \\
\text { baik }\end{array}$ & 7 & $38,8 \%$ \\
\hline \multirow{2}{*}{ Interaksi } & Baik & - & $0 \%$ \\
\cline { 2 - 4 } & Cukup & 3 & $16,7 \%$ \\
\hline
\end{tabular}




\begin{tabular}{|c|c|c|c|}
\hline Aspek & Kriteria & $\begin{array}{l}\text { Jumlah } \\
\text { Anak } \\
18 \text { Orang }\end{array}$ & Persentase \\
\hline & Baik & & \\
\hline & $\begin{array}{l}\text { Kurang } \\
\text { baik }\end{array}$ & 9 & $50,0 \%$ \\
\hline & $\begin{array}{l}\text { Tidak } \\
\text { baik }\end{array}$ & 6 & $33,3 \%$ \\
\hline \multirow{4}{*}{$\begin{array}{l}\text { Tanggung } \\
\text { Jawab }\end{array}$} & Baik & - & $0 \%$ \\
\hline & $\begin{array}{l}\text { Cukup } \\
\text { Baik }\end{array}$ & 4 & $22,2 \%$ \\
\hline & $\begin{array}{l}\text { Kurang } \\
\text { baik }\end{array}$ & 7 & $38,8 \%$ \\
\hline & $\begin{array}{l}\text { Tidak } \\
\text { baik }\end{array}$ & 7 & $38,8 \%$ \\
\hline
\end{tabular}

Kemampuan kerja sama anak kurang optimal disebabkan oleh beberapa hal, salah satunya upaya mengembangkan kemampuan kerja sama di Kelompok A TK Kartika Salo kurang maksimal. Upaya guru dalam mengembangkan kemampuan kerja sama terlihat pada saat kegiatan awal, guru biasanya menstimulasi kemampuan kerja sama anak hanya dengan metode cerita yang didalamnya ada nilai-nilai kerja sama. Namun upaya ini belum efektif mengembangkan kemampuan kerja sama anak karena anak merupakan pembelajar aktif dimana pembelajaran tersebut akan bermakna jika anak bertindak sebagai subjek, bukan hanya mendengarkan cerita dan nasehat.

Dari hasil wawancara peneliti dengan guru, diperoleh bahwa pembelajaran dalam bentuk kelompok ini jarang diberikan karena guru underestimate pada kemampuan anak-anak untuk berinteraksi secara kelompok. Guru beranggapan bahwa anak masih belum mampu untuk saling berbagi dan terlibat dalam kegiatan kerja kelompok.

Ada berbagai cara dalam mengembangkan kemampuan kerja sama, salah satunya dapat dilakukan melalui penerapan pembelajaran dengan kerja kelompok. Kerja kelompok merupakan salah satu strategi belajar mengajar dimana anak dibagi menjadi beberapa kelompok dan bekerja bersama dalam menyelesaikan tugas atau memecahkan masalah tertentu, dan berusaha mencapai tujuan bersama (Roestiyah N.K., 2001: 15).

Metode kerja kelompok untuk meningkatkan kemampuan kerja sama belum pernah dicoba di TK Kartika Salo. Berdasarkan uraian di atas, maka peneliti terdorong untuk mengambil judul penelitian "Upaya Meningkatkan Kemampuan Kerja Sama melalui Kegiatan Kerja Kelompok di Kelompok A TK Kartika Salo Kabupaten Kampar".

\section{Identifikasi Masalah}

Berdasarkan latar belakang masalah di atas, maka dapat diidentifikasikan beberapa masalah sebagai berikut: (1) kemampuan kerja sama anak belum optimal, (2) kurangnya kegiatan yang bersifat kelompok menyebabkan kemampuan bekerja sama kurang berkembang, (3) adanya anggapan guru bahwa anak TK belum mampu bekerja sama, dan (4) metode kerja kelompok belum pernah dicobakan untuk meningkatkan kemampuan bekerja sama.

Rumusan masalah pada penelitian ini adalah "Bagaimana meningkatkan kemampuan bekerja sama melalui kegiatan kerja kelompok pada anak Kelompok A di TK Kartika Salo Kabupaten Kampar?". Adapun tujuan dari penelitian ini adalah meningkatkan kemampuan bekerja sama anak kelompok A di TK Kartika Salo melalui kegiatan kerja kelompok.

Menghindari meluasnya penafsiran permasalahan yang akan dibahas dalam penelitian ini, maka perlu disampaikan definisi operasional sebagai berikut:

1. Kemampuan bekerja sama : Kemampuan bekerja sama adalah kemampuan anak dalam menyelesaikan tugas kelompok. Bekerja sama meliputi kemampuan anak agar mampu berinteraksi, saling membantu, dan bertanggung jawab dengan temannya.

2. Kegiatan kerja kelompok : Kegiatan kerja kelompok merupakan salah satu metode belajar-mengajar dimana anak dibagi menjadi beberapa kelompok untuk bekerja bersama dalam memecahkan masalah atau 
melaksanakan tugas tertentu, dan berusaha mencapai tujuan pengajaran yang telah ditentukan oleh guru, dengan tujuannya untuk meningkatkan kemampuan bekerja sama anak.

\section{Kajian Teori}

Tinjauan Perkembangan Sosial Anak Usia Dini Samsu Yusuff, LN (2006:122) mengartikan perkembangan sosial sebagai pencapaian kematangan dalam hubungan sosial. Dapat juga diartikan sebagai proses belajar untuk menyesuaikan diri terhadap norma-norma kelompok, moral dan saling berkomunikasi dan bekerja sama. Menurut Hurlock (1978: 250), perkembangan sosial berarti perolehan kemampuan berperilaku yang sesuai dengan tuntutan sosial. Menjadi orang yang mampu bermasyarakat (sosialized) memerlukan tiga proses. Masing-masing proses terpisah satu sama lain tetapi saling berkaitan, sehingga kegagalan dalam satu proses akan menurunkan kadar sosialisasi individu. Ketiga proses tersebut yakni: (1) Belajar berperilaku yang dapat diterima secara sosial, (2) memainkan peran sosial yang dapat diterima, (3) perkembangan sikap sosial,

Perkembangan sosial merupakan
kemampuan untuk dapat berperilaku sebagaimana mestinya agar dapat diterima dalam lingkungan masyarakat. Perkembangan sosial sangat dipengaruhi oleh dua faktor, yakni bimbingan orangtua terhadap anak dalam mengenalkan berbagai aspek kehidupan sosial, norma-norma sosial, serta mendorong dan memberikan contoh pada anak bagaimana menerapkan norma tersebut dalam kehidupan lazim. Faktor kedua dalam lingkungan sosial. Selain keluarga anak juga memiliki lingkungan sosial yang lebih luas yakni orang dewasa lainnya, teman sebaya, dan lingkungan sekolah yang meliputi teman sekolah, guru dan warga sekolah lainnya.

\section{Perkembangan Sosial Anak Usia Dini}

Yusuf, Samsu (2006:122), menyatakan bahwa anak dilahirkan tanpa membawa sifat sosial, artinya anak belum memiliki kemampuan untuk bergaul dengan orang lain. Untuk mencapai kematangan sosial, anak harus belajar tentang menyesuaikan diri dengan orang lain. Kemampuan ini diperoleh anak melalui berbagai kesempatan atau pengalaman bergaul dengan orang-orang di lingkungannya, baik orangtua, saudara, teman sebaya atau orang dewasa lainnya.

Hurlock (1978: 259), yang menjelaskan bahwa hanya sedikit bukti yang menunjukkan bahwa anak dilahirkan dalam keadaan bersifat sosial, tidak sosial, atau anti sosial, dan banyak bukti yang menunjukkan bahwa bayi atau anak bersifat demikian karena hasil belajar. Pola perilaku dalam situasi sosial pada masa kanakkanak awal meliputi: kerja sama, persaingan, kemurahan hati, hasrat akan penerimaan sosial, simpati, empati, ketergantungan, sikap ramah, sikap tidak mementingkan diri sendiri, meniru, dan perilaku kelekatan. Sedangkan perilaku non sosial meliputi: perlawanan, permusuhan, pertengkaran, mengejek dan menggertak, perilaku yang sok kuasa, egosentrisme, prasangka, dan antagonisme jenis kelamin.

\section{Tinjauan Kerjasama}

Kerja sama menurut Yusuf, Samsu (2004:125) adalah "sikap mau bekerja sama dengan kelompok". Sikap mau bekerja sama artinya dapat diajak dalam menyelesaikan sesuatu (kegiatan) secara bersama dalam suatu kelompok. Menurut Hurlock (1978:268), kerja sama merupakan kemampuan bekerja bersama menyelesaikan suatu tugas dengan orang lain. Dalam proses bekerja sama, anak dilatih untuk dapat menekan kepribadian individual dan mengutamakan kepentingan kelompok. Dari satu sisi anak memiliki sikap dalam melakukan kegiatan bersama dengan teman sebayanya, adanya sikap seperti itu anak mempunyai semangat bermain secara berkelompok.

Pendapat berbeda disampaikan Nasution (2010: 146) bahwa kerja sama merupakan salah satu dari asas didaktik atau asas dalam ilmu pendidikan. Lawan dari kerja sama ialah persaingan. Menurut Grambs (dalam Nasution, 
2010:147), baik kerja sama maupun persaingan sama pentingnya. Tujuan persaingan disini bukan semata-mata untuk memperoleh hadiah, akan tetapi untuk mencapai hasil yang lebih tinggi atau pemecahan masalah yang dihadapi kelompok.

Dari beberapa definisi diatas dapat disimpulkan bahwa kerja sama merupakan suatu sikap mau bekerja dengan orang lain atau kelompok. Setiap anak dilatih untuk mengutamakan kepentingan kelompok dan mengesampingkan kepentingan pribadi. Perbedaan-perbedaan yang terdapat pada diri anak dalam suatu kelompok dapat dijadikan sebagai kekuatan yang besar.

Kaitannya dengan karakteristik tehapan kerjasama, Yudha M. Saputra dan Rudyanto (2005:43-44) menyatakan empat langkah tahap kerja sama yakni: (1) bekerja sendiri, (2) mengamati dan mengenal lingkungan, (3) merasa tertarik dan mengadakan penyesuaian diri, dan (4) terbuka untuk memberi dan menerima, orang yang terlibat pada kerja sama harus mau dan mampu untuk saling memberi dan menerima. Sifat egosentris harus dikikis atau paling tidak dikurangi sehingga proses keterbukaan dapat berlangsung. Sedangkan David (Slamet Suyanto, 2005a:154) mengklasifikasikan empat elemen dasar dalam kerja sama, yaitu: adanya saling ketergantungan yang saling menguntungkan pada anak dalam melakukan usaha secara bersamasama, adanya interaksi langsung diantara anak dalam satu kelompok, masing-masing anak memiliki tanggung jawab untuk bisa menguasai materi yang diajarkan, penggunaan kemampuan interpersonal dan kelompok kecil secara tepat, yang dimiliki oleh setiap anak.

Dalam upaya mengembangkan kemampuan kerja sama dalam diri anak, guru di sekolah dapat menggunakan beberapa cara atau langkah-langkah untuk menumbuhkan kemampuan kerja sama anak. Langkah-langkah untuk menumbuhkan kemampuan kerja sama menurut Tadkiroatun Musfiroh, dkk.(2007:2022) adalah sebagai berikut: (1) mengenalkan permainan yang bersifat kerja sama (2) mengenalkan kasih saying (3) mengenalkan sikap gotong royong (4) mengajarkan anak untuk berbagi (5) mendorong anak untuk membantu dan (6) mengajarkan kesungguhan hati dalam membantu orang lain.

\section{Tinjauan Kerja Kelompok}

Kerja kelompok memiliki pengertian, dimana anak didik dalam suatu kelompok di pandang sebagai suatu kesatuan tersendiri, untuk mencapai tujuan tertentu dengan cara bergotong royong. Cara ini dapat menggerakkan anak untuk melakukan kerja sama sepenuh hati dengan kelompok. Menurut Gordon (Moeslichatoen, 2004: 138), kerja kelompok merupakan kegiatan belajar yang memungkinkan anak belajar untuk dapat mengatur diri sendiri agar dapat membina persahabatan, berperan serta dalam kegiatan kelompok, memecahkan masalah yang dihadapi kelompok, dan bekerja sama untuk mencapai tujuan bersama. Kerja kelompok merupakan suatu aktivitas kerja yang mana dalam aktivitas kerja tersebut terdapat suatu masalah maupun tugas yang harus diselesaikan secara bersama. Penyelesaian tugas diselesaikan dalam suatu kelompok yang mengharuskan adanya kerja sama dari antar anggota kelompok.

Ada tiga bentuk kerja kelompok menurut Roestiyah N.K. (2001:18-20), yaitu: (1) kerja kelompok berjangka pendek, (2) Kerja kelompok berjangka panjang, dan (3) kerja kelompok campuran.

Kelebihan dan kekurangan penggunaan kegiatan kerja kelompok dapat duraikan sebagai berikut. Pertama, kelebihan kegiatan kerja kelompok (1) dapat memberikan kesempatan pada anak untuk menggunakan keterampilan bertanya dan membahas suatu masalah, (2) dapat memberikan kesempatan pada anak untuk lebih intensif mengadakan penyelidikan mengenai suatu masalah, (3) dapat mengembangkan bakat kepemimpinan dan mengajarkan keterampilan berdiskusi, (4) dapat memungkinkan guru untuk lebih memperhatikan anak sebagai individu serta kebutuhannya belajar, (5) anak lebih aktif tergabung dalam pelajaran mereka dan lebih aktif berpartisipasi dalam kelompoknya dan (6) 
anak dapat mengembangkan sikap saling menghargai dan menghormati pribadi temannya, menghargai pendapat orang lain, dan saling membantu dalam kelompok untuk mencapai suatu tujuan. Kedua, kekurangan-kekurangan kegiatan kerja kelompok yaitu: (1) kerja kelompok lebih sering hanya melibatkan mereka yang mampu karena mereka cakap memimpin dan bisa mengarahkan mereka yang kurang mampu, (2) strategi ini kadang-kadang menuntut pengaturan tempat duduk yang berbeda- beda dan gaya mengajar yang berbeda pula dan (3) keberhasilan strategi kelompok ini tergantung kepada kemampuan anak memimpin kelompok atau untuk bekerja sendiri.

\section{Penelitian yang Relevan}

Untuk menghindari duplikasi dan sebagai bahan referensi bagi penelitian ini, maka peneliti cantumkan penelitian yang relevan terhadap penelitian ini.

Pertama, penelitian oleh Nurul Hidayah (2012) yang berjudul "Upaya Membiasakan Anak untuk Memelihara Kebersihan Lingkungan dengan Kerja Kelompok di Raudhatul Athfal Bligo I Ngluwar Kabupaten Magelang”. Penelitian ini melibatkan 14 anak terdiri dari 4 anak laki-laki dan 10 anak perempuan. Berdasarkan hasil penelitian, diperoleh hasil bahwa kemampuan memelihara kebersihan lingkungan di dalam dan di luar ruangan, membersihkan tempat makan dan peralatan makan, membuat dan merawat taman bunga meningkat.

Kedua, penelitian oleh Endah Prayuanti (2013) yang berjudul "Peningkatan Kemampuan Bekerja Sama melalui Metode Bermain pada Anak Kelompok B di TK PKK 54 Pucung Pendowoharjo Sewon Bantul". Hasil penelitian menunjukkan bahwa metode bermain kooperatif seperti bermain estafet karet gelang dan masinis gerbong kereta api dapat meningkatkan kemampuan bekerja sama setelah dilakukan tindakan. Dari hasil yang diperoleh dapat disimpulkan bahwa kemampuan bekerja sama dapat ditingkatkan melalui metode bermain kooperatif.
Ketiga, penelitian oleh Nola Sanda Rekysika (2015) yang berjudul "Upaya Meningkatkan Kemampuan Kerja Sama Melalui Kegiatan Kerja Kelompok Di Kelompok A TK Negeri Trukan Siwates Kaligintung Temon Kulon Progo". Penelitian melibatkan 18 anak Kelompok A TK Negeri Trukan Siwates Kaligintung Temon Kulon Progo yang terdiri dari 9 anak laki-laki dan 9 anak perempuan. Hasil penelitian menunjukkan bahwa kemampuan kerja sama anak meningkat hal ini dapat dilihat pada Siklus I persentase kemampuan kerja sama anak meningkat menjadi 65\%. Pada Siklus II kemampuan kerja sama anak kembali mengalami peningkatan menjadi $93 \%$. Dapat dikatakan bahwa penelitian ini berhasil karena persentase sudah mencapai angka yang ditentukan, yakni 80\%. Kegiatan kerja kelompok yang diberikan dalam penelitian ini berupa mewarnai gambar, menyusun puzzle, memilah biji dan mix media. Adapun langkah-langkah yang ditempuh dalam kegiatan kerja kelompok yaitu guru mempersiapkan media pembelajaran, guru dan anak membentuk kelompok, guru menunjuk pemimpin, anak membagi tugas dalam kelompok. Setelah kegiatan kelompok usai, guru membagikan reward di akhir kegiatan untuk memotivasi anak

\section{Kerangka Pemikiran}

Perkembangan sosial adalah pencapaian kematangan dalam hubungan sosial. Dapat juga diartikan sebagai proses belajar untuk menyesuaikan diri terhadap norma-norma kelompok, moral dan saling berkomunikasi dan bekerja sama. Kemampuan kerja sama merupakan salah satu kemampuan dalam aspek perkembangan sosial-emosional. Menurut Takdiroatun Musfiroh, Ni Nyoman Seriati dan Yulia Ayriza (2007:17), kerja sama penting untuk diajarkan sejak dini karena kemampuan kerja sama sangat dibutuhkan dalam kehidupan bermasyarakat. Melalui kerja sama, anak akan dapat membina hubungan yang lebih baik dengan teman-temannya karena dalam kerja sama terdapat beberapa sikap positif seperti adanya interaksi, sikap saling membantu, dan tanggung jawab. 
Hipotesis Tindakan

Berdasarkan kajian teori dan kerangka pikir di atas maka diajukan hipotesis tindakan bahwa kegiatan kerja kelompok dapat meningkatkan kemampuan kerja sama pada anak Kelompok A di TK Kartika Salo Kabupaten Kampar.

\section{Metode Penelitian}

Penelitian ini menggunakan pendekatan penelitian tindakan kelas (PTK). Arikunto (2008:58) mendefinisikan penelitian tindakan kelas (PTK) dengan menggabungkan batasan tiga pengertian tiga kata inti, yaitu (1) penelitian, (2) tindakan, (3) kelas, yaitu penelitian tindakan (classroom action research) merupakan penelitian yang dilakukan dengan tujuan memperbaiki pembelajaran di kelas.

Penelitian tindakan kelas ini bertujuan untuk menemukan metode pembelajaran yang dapat meningkatkan kemampuan bekerja sama anak Kelompok A TK Kartika Salo. Penelitian ini digunakan sebagai bahan masukan pendidik dan calon pendidik dalam proses kegiatan pembelajaran. Penelitian ini direncanakan dua siklus dan setiap siklus terdiri dari dua pertemuan. Pada akhir siklus pertama dilakukan refleksi yang digunakan sebagai referensi perbaikan untuk pelaksanaan tindakan siklus kedua.

Subjek penelitian ini adalah anak di Kelompok A TK Kartika Salo Kabupaten Kampar. Jumlah Kelompok A secara keseluruhan berjumlah 18 anak terdiri dari 9 anak perempuan dan 9 anak laki- laki. Peneliti memilih Kelompok A karena kemampuan dalam hal bekerja sama untuk sebagian besar anak masih kurang optimal karena masih ada beberapa anak yang belum mampu bekerja sama dengan teman yang lainnya. Penelitian ini dilaksanakan di TK Kartika Salo Kabupaten kampar Propinsi Riau. Penelitian ini dilaksanakan pada bulan Februari sampai April atau pada Semester Genap Tahun Ajaran 2015/2016.
Desain penelitian menggunakan model Kemmis dan McTaggart pada gambar berikut ini

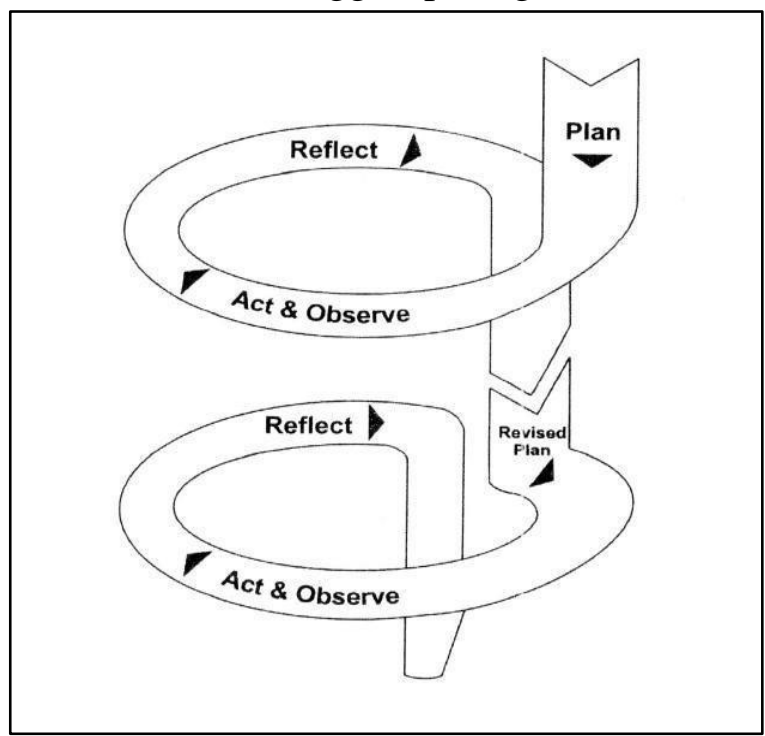

Gambar 2.1 Desain Penelitian Tindakan Kelas Model Kemmis dan McTaggart

\section{Teknik Pengumpulan Data}

Variasi metode pengumpulan data adalah angket, wawancara, pengamatan atau observasi, tes, dan dokumentasi. Penelitian ini menggunakan metode pengumpulan data yaitu observasi. Observasi dilakukan dengan mengamati kegiatan pada proses pembelajaran, memperhatikan apa yang terjadi, mendengarkan, mempertanyakan informasi yang menarik, mempelajari dokumen yang ada (Idrus Muhammad 2007:129). Observasi dilakukan dengan menggunakan lembar observasi yang telah disiapkan peneliti.

\section{Instrumen Penelitian}

Pengumpulan data dalam penelitian ini menggunakan instrumen penelitian yang berupa lembar observasi. Lembar observasi digunakan peneliti untuk mencatat hasil pengamatan atau observasi yang dilakukan secara langsung oleh peneliti selama siklus berlangsung. Pedoman pengisiannya praktis, dengan membubuhkan tanda chek list $(\sqrt{ })$ jika hal yang diamati muncul.

Instrumen penelitian yang digunakan dalam penelitian ini dijelaskan pada Tabel 1 berikut:

Tabel 1. Rubrik Penilaian Check List tentang Kemampuan Bekerja Sama 


\begin{tabular}{|c|c|c|}
\hline $\begin{array}{l}\text { Aspek yang } \\
\text { diamati }\end{array}$ & Sko & Deskripsi \\
\hline \multirow{4}{*}{$\begin{array}{l}\text { Anak mampu } \\
\text { berinteraksi } \\
\text { dengan teman } \\
\text { kelompoknya }\end{array}$} & 4 & $\begin{array}{l}\text { Jika anak } \\
\text { dapat } \\
\text { berkomunikasi }\end{array}$ \\
\hline & 3 & $\begin{array}{l}\text { Jika anak } \\
\text { dapat }\end{array}$ \\
\hline & 2 & $\begin{array}{l}\text { harl-ammikaci } \\
\text { Jika anak } \\
\text { dapat } \\
\text { herkomunikasi }\end{array}$ \\
\hline & 1 & $\begin{array}{l}\text { Jika anak belum } \\
\text { dapat }\end{array}$ \\
\hline \multirow{5}{*}{$\begin{array}{l}\text { Anak dapat } \\
\text { menyelesaikan } \\
\text { tugas yang } \\
\text { telah dibagi } \\
\text { dalam } \\
\text { kelompoknya }\end{array}$} & 4 & $\begin{array}{l}\text { Jika anak dapat } \\
\text { menyelesaikan }\end{array}$ \\
\hline & 3 & $\begin{array}{l}\text { tuoas vano telah } \\
\text { Jika anak dapat } \\
\text { menyelesaikan }\end{array}$ \\
\hline & & Jika anak dapat \\
\hline & 2 & \\
\hline & 1 & $\begin{array}{l}\text { Jika anak belum } \\
\text { dapat }\end{array}$ \\
\hline \multirow{4}{*}{$\begin{array}{l}\text { Anak dapat } \\
\text { membantu } \\
\text { teman yang } \\
\text { kesulitan } \\
\text { dalam } \\
\text { mengerjakan } \\
\text { tugas } \\
\text { kelompok }\end{array}$} & 4 & $\begin{array}{l}\text { Jika anak } \\
\text { dapat } \\
\text { membantu }\end{array}$ \\
\hline & 3 & $\begin{array}{l}\text { Jika anak } \\
\text { dapat } \\
\text { membantw }\end{array}$ \\
\hline & 2 & $\begin{array}{l}\text { Jika anak } \\
\text { dapat saling } \\
\text { membantu }\end{array}$ \\
\hline & 1 & $\begin{array}{l}\text { Jika anak } \\
\text { belum dap }\end{array}$ \\
\hline
\end{tabular}

\section{Teknik Analisis Data}

Penelitian ini menggunakan teknik analisis kuantitatif. Deskriptif kuantitatif adalah data yang diperoleh berupa angka-angka untuk mengetahui persentase kemampuan bekerja sama anak. Teknik analisis data dalam penelitian ini dilakukan dengan cara merefleksi hasil observasi terhadap proses pembelajaran yang dilaksanakan oleh pendidik dan anak di kelas.

\section{Hasil Penelitian}

Hasil dari pelaksanaan Siklus I dengan menggunakan instrumen lembar observasi pada indikator pertama yaitu dapat berinteraksi dengan kelompok, pada kriteria baik persentase yang dicapai adalah $17 \%$ atau dari 16 anak, yang mendapat kriteria baik sebanyak 2 anak. Pada kriteria cukup baik, persentase yang dicapai adalah $67 \%$ atau dari 4 anak, yang mendapat kriteria cukup baik sebanyak 12 anak. Indikator ketiga adalah saling membantu adalah $22 \%$ atau dari 16 anak, yang mendapat kriteria kurang sebanyak 3 anak. Pada Siklus I ini tidak ada anak yang mendapatkan kriteria sangat kurang.Persentase terbanyak masih pada kriteria cukup baik, hal ini karena sebagian anak masih belum dapat berinteraksi dengan teman sekelompoknya sesuai dengan yang diharapkan peneliti. Interaksi yang dimaksud peneliti adalah obrolan maupun tindakan anak dengan teman kelompoknya yang membahas mengenai tugas kelompok, bukan membahas hal di luar tugas.

Hasil dari pelaksanaan Siklus II dengan menggunakan instrumen lembar observasi pada indikator pertama yaitu dapat berinteraksi dengan kelompok, pada kriteria baik persentase yang dicapai adalah $78 \%$ atau dari 18 anak, yang mendapat kriteria baik sebanyak 14 anak. Pada kriteria cukup baik, persentase yang dicapai adalah 22\% atau dari 18 anak, yang mendapat kriteria cukup baik sebanyak 4 anak. Pada Siklus I ini tidak ada anak yang mendapatkan kriteteria kurang dan sangat kurang. Persentase terbanyak berada pada kriteria baik, sebagian besar anak sudah dapat berinteraksi dengan teman sekelompoknya sesuai dengan yang diharapkan peneliti. Interaksi yang dimaksud peneliti adalah obrolan maupun tindakan anak dengan teman kelompoknya yang membahas mengenai tugas kelompok, bukan membahas hal di luar tugas.

Indikator yang kedua adalah tanggung jawab dalam mengerjakan tugas kelompok. Persentase yang dicapai pada kriteria baik adalah 94\%, atau dari 18 anak, yang mendapat kriteria baik sebanyak 17 anak. Pada kriteria cukup baik, persentase yang dicapai adalah 6\%, atau dari 18 anak, yang mendapat skor kriteria cukup baik sebanyak 1 anak. Tidak ada anak yang berada pada kriteria kurang dan sangat 
kurang. Persentase tertinggi berada pada kriteria baik, ini karena sebagian besar anak sudah dapat bertanggung jawab penuh terhadap tugas kelompok.

Indikator yang ketiga adalah mampu membantu teman yang kesulitan dalam mengerjakan tugas kelompok. Kriteria baik, persentase yang dicapai $83 \%$, atau dari 16 anak, yang mendapat kriteria baik sebanyak 14 anak. Pada kriteria cukup, persentase mencapai 17\%, atau dari 16 anak, yang mendapat kriteria cukup sebanyak 2 anak. Tidak ada yang berada pada kriteria kurang dan sangat kurang. Persentase tertinggi berada pada kriteria baik, karena sebagian besar anak masih sudah dapat membantu teman satu kelompoknya yang mengalami kesulitan.

Indikator yang kedua adalah tanggung jawab dalam mengerjakan tugas kelompok. Persentase yang dicapai pada kriteria baik adalah $11 \%$, atau dari 16 anak, yang mendapat kriteria baik sebanyak 1 anak. Pada kriteria cukup baik, persentase yang dicapai adalah $44,5 \%$, atau dari 16 anak, yang mendapat skor kriteria cukup baik sebanyak 7 anak. Kriteria kurang, persentase yang dicapai adalah 44,5\%, atau dari 16 anak, yang mendapat skor kriteria kurang baik ada. Tidak ada yang berada pada kriteria sangat kurang, akan tetapi persentase tertinggi masih pada kriteria kurang dan kriteria cukup baik. Beberapa anak masih belum menyadari bahwa dalam kerja kelompok, bertanggung jawab secara individu sangat diperlukan.Hal ini disebabkan belum adanya pembagian tugas yang jelas.

Indikator yang ketiga adalah mampu membantu teman yang kesulitan dalam mengerjakan tugas kelompok. Kriteria baik, persentase yang dicapai 22\%, atau dari 16 anak, yang mendapat kriteria baik sebanyak 4 anak. Pada kriteria cukup, persentase mencapai $67 \%$, atau dari 16 anak, yang mendapat kriteria cukup sebanyak 12 anak. Kriteria ketiga yaitu kurang baik, persentasenya mencapai $11 \%$, atau dari 16 anak, yang mendapat kriteria kurang baik sebanyak 2 anak. Tidak ada yang berada pada kriteria sangat kurang, akan tetapi persentase tertinggi berada pada kriteria cukup baik, karena beberapa anak masih belum dapat membantu teman satu kelompoknya yang mengalami kesulitan.

Berdasarkan penjelasan di atas terlihat bahwa kermampuan kerja sama anak Kelompok A TK Kartika Salo Kabupaten kampar mengalami peningkatan. Hal ini terbukti dengan naiknya presentase kemampuan kerja sama anak Kelompok A secara keseluruhan, yakni pada Siklus I persentase kemampuan kerja sama secara keseluruhan adalah $65 \%$, pada Siklus II meningkat menjadi $93 \%$.

\section{Pembahasan}

Kemampuan kerja sama anak pada akhir Siklus I sudah mulai terlihat.Anak sudah mulai dapat berinteraksi dengan teman kelompok saat mengerjakan tugas, dapat saling membantu dan sudah ada sebagian yang mampu bertanggung jawab dengan tugas kelompok. Hal tersebut sesuai dengan teori Partern (Santrock, 2002: 273274) yang menyatakan bahwa tahapan cooperative play atau bermain secara kelompok dan kerja sama sudah terlihat pada tahun- tahun prasekolah dan masa pertengahan anak. Meski demikian, masih ada sebagian anak yang diam bahkan melamun dan tidak memperhatikan teman kelompok.Kemampuan kerja sama anak masih harus ditingkatkan. Pada Siklus I ini persentase kemampuan kerja sama anak secara keseluruhan adalah $65 \%$.

Peneliti dalam melaksanakan Siklus I mengalami beberapa kendala, sehingga perlu diadakan perbaikan untuk Siklus II agar indikator keberhasilan dapat tercapai. Kendala pada Siklus I adalah ketika guru membentuk kelompok sendiri tanpa melibatkan anak, kelompok sulit terbentuk, kadang anak juga masih pilih-pilih teman. Guru hanya menunjuk anak untuk berkumpul menjadi satu kelompok dan terkadang anak lambat untuk mengikuti instruksi guru. Dalam kegiatan kerja kelompok anak juga masih asal mengerjakan tugas, terkadang anak berebut bagian tugas dan tidak jarang ada keributan kecil. Anak juga kurang 
antusias dalam melakukan kegiatan kerja kelompok.

Dari kendala-kendala yang ada dalam Siklus I tersebut, maka peneliti dan guru berdiskusi untuk melakukan perbaikan. Guru melibatkan anak dalam pembentukan kelompok dengan cara mengambil undian sehingga anak merasa bahwa kelompok tersebut terbentuk karena partisipasinya dan anak lebih mudah diatur untuk duduk dan mengerjakan tugas dengan kelompoknya. Selain itu pembentukan kelompok yang melibatkan anak dengan cara mengambil undiansendiri-sendiri dapat membentuk kelompok yang heterogen atau berbeda prestasi, kecerdasan, etnik dan jenis kelamin. Ini dapat menghapus kemungkinan anak pilih-pilih teman kelompok.Hal ini dikuatkan oleh Nur Asma (2006: 19) bahwa mencampurkan anak berdasarkan prestasi dan kecerdasandapat membangun sistem tutur teman sebaya, sedangkan mencampur anak berdasar etnik dan jenis kelamin dapat membawa perspektif unik dalam kelompok.

Perbaikan selanjutnya pada Siklus II yakni adanya pemimpin dalam setiap kelompok. Guru menunjuk 1 anak dari masing-masing kelompok untuk menjadi pemimpin. Sesuai dengan pendapat Roestiyah N.K. (2001: 17) bahwa salah satu kelebihan kerja kelompok adalah dapat mengembangkan bakat kepemimpinan dan mengajarkan keterampilan berdiskusi. Guru menunjuk dengan cara bergantian setiap harinya.

Perbaikan selanjutnya pada Siklus II ini kegiatan dibuat sedemikian rupa agar anak mudah dalam membagi tugas dalam satu kelompok. Ketika anak memiliki satu tugas yang jelas dalam kelompok, maka rasa tanggung jawab akan muncul pada diri anak. Anak akan memiliki tanggung jawab untuk menyelesaikan bagian tugasnya tersebut.Hal ini sesuai dengan yang dikemukakan oleh Ishjoni(2010: 34) bahwa keberhasilan kelompok tergantung dari pembelajaran individu dalam kelompok tersebut. Adanya pertanggung jawaban secara individu dapat menjadikan setiap anggota kelompok dapat mengerjakan tugasnya baik tanpa bantuan teman maupun dengan bantuan temannya ketika dia kesulitan.Senada dengan pendspat tersebut, David (dalam Slamet Suyanto, 2005:154) menyatakan bahwa bahwa dalam kegiatan kerja kelompok terdapatinteraksi langsung antara anggota kelompok dan masing-masing anak harus memiliki tanggung jawab dalam tugasnya.

Perbaikan terakhir adalah memberikan reward disetiap akhir kegiatan. Pemberian reward ini memiliki pengaruh besar terhadap semangat anak dalam mengerjakan tugas kelompoknya.Hal ini dikuatkan oleh pendapat Dimyati dan Mudjiono (2006: 85-86) yang menjelaskan bahwa ketika motivasi diketahui oleh anak, maka tugas belajar, dalam hal ini kerja kelompok, dapat terselesaikan dengan baik. Motivasi dapat membangkitkan, meningkatkan dan memelihara semangat anak untuk belajar. Membangkitkan ketika anak tidak bersemangat, meningkatkan ketika semangat anak timbul tenggelam, dan memelihara ketika semangatnya telah kuat untuk mencapai tujuan pembelajaran.

Peneliti dan guru sepakat memberikan reward berupa pujian dan hadiah. Ishjoni (2010: 33-34) mengemukakan bahwa reward atau penghargaan kelompok diberikan jika skor kriteria kelompok tersebut dapat meningkat dari sebelumnya. Keberhasilan kelompok didasarkan pada individu sebagai anggota kelompok dalam menciptakan hubungan baik yang saling mendukung, saling membantu, saling peduli dengan teman sekelompoknya dan tanggung jawab dengan tugasnya. Dengan adanya reward, anak semakin termotivasi untuk bekerja lebih baik dalam kelompoknya. Peneliti dan guru menyiapkan rewardyang serupa tapi berbeda pada setiap hari, anak juga diberitahu mengenai reward yang akan didapat hari tersebut sebelum mengerjakan tugas kelompok.

Kemampuan bekerja sama anak pada Siklus II dengan adanya perbaikan dari Siklus I telah terbukti mengalami peningkatan. Hal ini dapat dilihat dari persentase kemampuan kerja sama anak secara keseluruhan. Yakni pada Siklus I, persentase kemampuan kerja sama 
anak adalah 65\%. Pada Siklus II meningkat menjadi $93 \%$.

Dari hasil penelitian tersebut dapat dikatakan bahwa pembelajaran kerja kelompok pada dasarnya sudah dapat digunakan di TK akan tetapi harus disesuaikan dengan karakterisktik anak. Pembelajaran dengan kerja kelompok dapat melatih kerja sama anak yang meliputi berbagai unsur seperti kemampuan berinteraksi dengan teman kelompok,saling membantu dengan teman kelompok dan tanggung jawab dengan tugas kelompoknya. Hal ini sejalan dengan pendapat Gordon (Moeslichatoen, 2004: 138), bahwa kerja kelompok merupakan kegiatan belajar yang memungkinkan anak belajar untuk dapat mengatur diri sendiri agar dapat membina persahabatan, berperan serta dalam kegiatan kelompok, memecahkan masalah yang dihadapi kelompok, dan bekerja sama untuk mencapai tujuan bersama

\section{DAFTAR PUSTAKA}

Acep Yoni. (2010). Menyusun Penelitian

Tindakan Kelas. Yogyakarta. Familia.

Achmad Sabri. (2005). Strategi Belajar

Mengajar dan Micro Teaching. Jakarta: Grasindo.

Ali Nugraha \& Yeni Rachmawati. (2005).

Metode Pengembangan Sosial

Emosional. Jakarta: Universitas Terbuka.

Aunurrahman. (2010). Belajar dan Pembelajaran.

Bandung: Alfabeta.

Djam'an Satori \& Aan Komariah. (2011).

Metodelogi Penelitian Kualitatif.

Bandung: Alfabet.

Dimyati \& Mudjiono. (2006). Belajar dan

Pembelajaran. Jakarta: PT. Rineka Cipta.

Farida Agus Setiawati, Ikhsan Wasesa, \& Aswarni Sudjud. (2007). Empati. Yogyakarta: Tiara Wacana.

Hurlock, E.B. (1978a). Perkembangan Anak. Jakarta: Erlangga. Hurlock, E.B. (1980b). Psikologi Perkembangan. Jakarta:
Erlangga. Ishjoni. (2010). Pembelajaran Kooperatif. Yogyakarta: Pustaka Pelajar.

Johnson, E.B. (2008). Contextual Teaching and Learning. (Alih bahasa: Ibnu Setiawan). Bandung: Mizan Learning Center.

J.J Hasibuan \& Moedjiono. (2006). Proses

Belajar Mengajar. Bandung: PT Remaja Rosdakarya.

Karli \& Yuliariatiningsih, M.S. (2002).

Implementasi Kurikulum Berbasis Kompeten. Model-Model Pembelajaran. Jakarta: Bina Media Informasi.

Lwin, May, Adam Khoo, Keneeth Lyen, \&

Caroline Sim. (2008). Cara

Mengembangkan Berbagai Komponen

Kecerdasan. (Alih bahasa: Christine

Sujana). -----. PT Indeks.

Moeslichatoen. (2004). Metode Pengajaran di

Taman Kanak-Kanak. Jakarta: PT Rineka Cipta.

Nasution. (2010). Didaktik Asas-asas Mengajar. Jakarta: Bumi Aksara.

Nur Asma. (2006). Model Pembelajaran

Kooperatif. Jakarta: Departemen

Pendidikan Nasional Direktorat Jenderal

Pendidikan Tinggi Direktorat

Ketenagaan.

P. Daeng Sari Dini. (1996). Metoda Mengajar di Taman Kanak-Kanak. Jakarta.

Departemen Pendidikan dan Kebudayaan

Direktorat Jenderal Pendidikan Tinggi

Proyek Pendidikan Tenaga Akademik.

Reni Akbar-Hawadi, Ike Anggraini

Setyowati, \& Khairunnisa. (2009).

Bekerjasama. Jakarta: PT Raja Grafindo Persada.

Roestiyah N.K. (2001). Strategi Belajar Mengajar. Jakarta: PT Rineka Cipta. Sa'dun Akbar. (2010). Penelitian Tindakan Kelas.

Yogyakarta: Cipta Media. Santrock, J.W. (2002a). Perkembangan Masa Hidup.

Jakarta: Erlangga. 
Santrock. J.W. (2010b). Psikologi Pendidikan. Jakarta: PT Fajar Interpratama Offset.

Slamet Suyanto. (2005a). Dasar-Dasar Pendidikan Anak Usia Dini. Yogyakarta: Hikayat Publishing.

Slamet Suyanto. (2005b). Konsep Dasar Pendidikan Anak Usia Dini. Jakarta: Departemen Pendidikan Nasional Direktorat Jenderal Pendidikan Tinggi Direktorat Pembinaan Pendidikan Tenaga Kependidikan dan Ketenagaan Perguruan Tinggi.

Soemiarti Patmonodewo. (2003). Pendidikan Anak Prasekolah. Jakarta: PT Rineka Cipta.

Sofia Hartati. (2005). Perkembangan Belajar Pada Anak Usia Dini. Jakarta: Departemen Pendidikan Nasional Direktorat Pendidikan Tinggi Direktorat Pembinaan Pendidikan Tenaga Kependidikan \& Ketenagaan Perguruan Tinggi.

Suharsimi Arikunto. (2006a). Prosedur Penelitian Suatu Pendekatan Praktik. Jakarta: Rineka Cipta.

Suharsimi Arikunto, Suhardjono, dan Supardi. (2008b). Penelitian Tindakan Kelas. Jakarta: Bumi Aksara.

Suharsimi Arikunto, Suhardjono, dan Supardi. (2010c). Penelitian Tindakan Kelas. Jakarta: Bumi Aksara.

Syaiful Sagala. (2010). Konsep dan Makna

Pembelajaran. Bandung: Alfabeta.

Syamsu Yusuf LN. (2006).

Psikologi Perkembangan. Bandung:

Remaja Rosdakarya.

Tadkiroatun Musfiroh, Ni Nyoman Seriati, \& Yulia Ayriza. (2007). Afiliasi Resolusi Konflik. Yogyakarta: Tiara Wacana.

Wijaya Kusuma \& Dedi Dwitagama. (2010). Mengenal Penelitian Tindakan Kelas Edisi Kedua. Jakarta: Indeks Permata Puri Media.
W.J.S Poerwadarminta. (2002). Kamus Umum Bahasa Indosesia. Jakarta: Balai Pustaka.

Yudha M. Saputra dan Rudyanto. (2005). Pembelajaran Kooperatif Untuk Meningkatkan Ketrampilan Anak TK. Jakarta: Departemen Pendidikan Nasional Direktorat Jenderal Pendidikan Tinggi Direktorat Pembinaan Pendidikan Tenaga Kependidikan dan Ketenagaan Perguruan Tinggi.

----. (2006). Pedoman Pembelajaran di Taman

Kanak-kanak. Jakarta: Departemen Pendidikan Nasional Direktorat Jenderal Manajemen Pendidikan Dasar dan Menengah Direktorat Pembinaan TK dan SD.

----. (2006). Panduan Bimbingan Di TK.

Jakarta: Departemen Pendidikan

Nasional Direktorat Jenderal

Manajemen Pendidikan Dasar dan Menengah. 